\title{
Helminths of the marine tucuxi, Sotalia fluviatilis (Gervais, 1853) (Cetacea: Delphinidae), in northern Rio de Janeiro State, Brazil
}

\author{
Osana Prado Melo ${ }^{1}$, Renata Maria Arruda Ramos ${ }^{2}$ and Ana Paula Madeira Di Beneditto ${ }^{{ }^{*}}$ \\ ${ }^{I}$ Universidade Estadual do Norte Fluminense - UENF; CBB; Laboratório de Ciências Ambientais; Av. Alberto \\ Lamego, 2000; 28013-600; Campos do Goytacazes - RJ - Brasil. ${ }^{2}$ Everest Tecnologia em Serviços Ltda.; Av. N. S. \\ dos Navegantes, 675/1201; 29056-900; Vitória - ES - Brasil
}

\begin{abstract}
The objectives of this work were to reporte the helminths of the marine tucuxi, Sotalia fluviatilis (Cetacea: Delphinidae) in northern Rio de Janeiro State; and to check if the infestation rate varied with the host characteristics (sex and maturity) and year seasons. From 1989 to 2002, 80 marine tucuxis that were by-caught in fisheries were examined and four parasites were recorded: Braunina cordiformis, Anisakis typica, Halocercus brasiliensis and Nasitrema sp. The parasitism in the marine tucuxi corroborated its feeding habits and there were no infestation rate differences between males and females, youngs and adults, as well as between year seasons. This work reports for the first time the occurrence of the genus Nasitrema in the marine tucuxi.
\end{abstract}

Key words: Sotalia fluviatilis, marine tucuxi, helminths, Rio de Janeiro State, Brazil

\section{INTRODUCTION}

Sotalia fluviatilis (Gervais, 1853) (Cetacea: Delphinidae), known as tucuxi, occurs in Central and South America, including the basins of Amazon and Orinoco Rivers (Borobia et al., 1991). Two different ecotypes are recognized based on skull and body dimensions: marine and fluvial forms (Jefferson et al., 1993). Marine tucuxi inhabits coastal and estuarine waters and despite its continuous occurrence along the distributional range, it is one of the less studied delphinids.

In the Brazilian coast, the knowledge about the parasites associated with the marine tucuxi is still scarce. Previous studies were based on few specimens stranded on the beach or by-caught in fisheries (e.g. Borobia and Barros, 1989; Da Silva and Best, 1996; Marigo et al., 1999). Santos et al., (1996) carried out the first quantitative study about the parasitism of this cetacean, analyzing 23 specimens from northern Rio de Janeiro State.

The objectives of the present work were to report the parasites of this cetacean in northern Rio de Janeiro State, adding new information to the study conducted by Santos et al. (1996); and to check if the infestation rate varies with the host characteristics (sex and maturity) and year seasons.

\footnotetext{
${ }^{*}$ Author for correspondence.
} 


\section{MATERIALS AND METHODS}

From 1989 to 2002, 80 specimens of the marine tucuxi were collected as by-catch in fisheries carried out between Barra do Itabapoana $\left(21^{\circ} 18^{\prime} \mathrm{S}\right.$, $40^{\circ} 45^{\prime} \mathrm{W}$ ) and Macaé $\left(22^{\circ} 25^{\prime} \mathrm{S}, 41^{\circ} 46^{\prime} \mathrm{W}\right.$ ) (Figure 1). The host characteristics considered in this work were sex (male and female) and maturity (young and adult). The last one was estimated according to Ramos et al. (2000) which considered males and females as adults when $\geq 6$ years old and body length $\geq 180.0 \mathrm{~cm}$ and $\geq 6$ years old and body length $\geq 160.0 \mathrm{~cm}$, respectively. The year seasons were grouped into spring-summer, from October to March; and autumn-winter, from April to
September. These seasons included the highest and lowest recorded values of temperature and rainfall, respectively (Martin et al., 1998).

The cetaceans were necropsied and the stomachs, intestines, lungs, liver, heart, gonads and nasal cavity were only macroscopically examined to verify the helminths presence. Prevalence and mean intensity were calculated following Bush et al. (1997). The Chi-square test (Zar, 1996) was used to compare the infestation rate between the hosts.

Parasites recovered were fixed in 5\% formalin and were deposited in the collection from Laboratório de Ciências Ambientais, UENF.

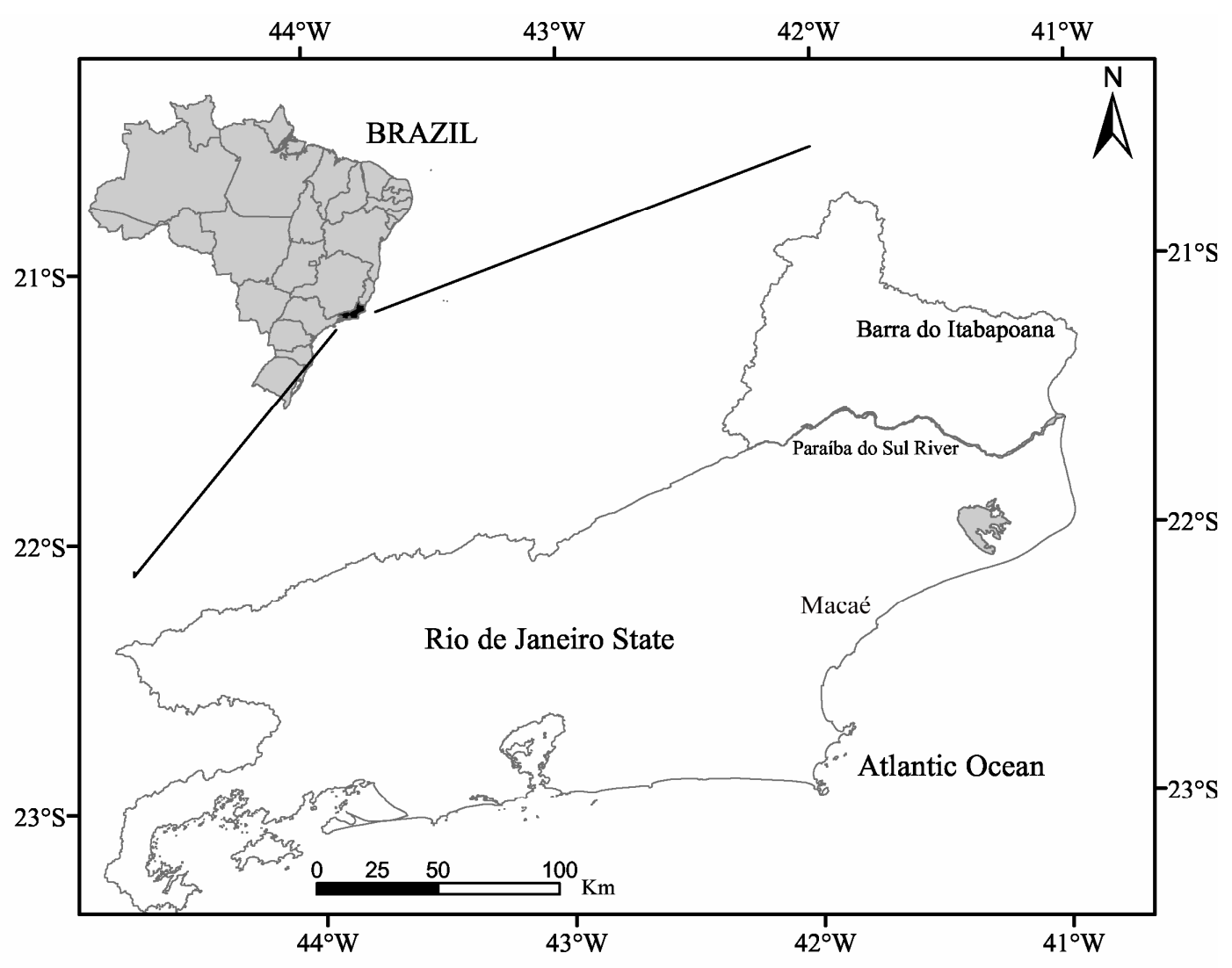

Figure 1 - Map of Rio de Janeiro State with the geographics limits of the northern coast (Barra do Itabapoana and Macaé).

\section{RESULTS}

Four parasite species were identified: two Nematoda, Anisakis typica and Halocercus brasiliensis; and two Trematoda, Braunina cordiformis and Nasitrema sp. Overall prevalence was $50 \%(\mathrm{~N}=80)$, representing 40 animals infested. B. cordiformis was found in the second and third stomach compartment of 26 animals; $A$. typica in the first stomach of 19 animals; $H$. brasiliensis in the lungs of five animals; and Nasitrema sp. in the nasal cavity of eight animals. 
Prevalence and mean intensity of parasite species are shown in Table 1. Comparisons between the marine tucuxis infested did not show significant differences $(p>0,05)$ for the variables sex, maturity and year seasons.

Table 1 - Prevalence and mean intensity of the parasite species in the marine tucuxi, Sotalia fluviatilis, from northern Rio de Janeiro State.

\begin{tabular}{lrrrrc}
\hline Parasite species & n & N & Prevalence & Mean intensity \pm SD & Range of intensity \\
\hline $\begin{array}{l}\text { Nematoda } \\
\text { Anisakis typica }\end{array}$ & 19 & 138 & $23.75 \%$ & $7.3 \pm 11.8$ & $1-49$ \\
$\begin{array}{l}\text { Halocercus } \\
\text { brasiliensis }\end{array}$ & 5 & 26 & $6.25 \%$ & $5.2 \pm 4.2$ & $1-15$ \\
$\begin{array}{l}\text { Trematoda } \\
\text { Braunina }\end{array}$ & & & & & \\
$\begin{array}{l}\text { cordiformis } \\
\text { Nasitrema } \text { sp }\end{array}$ & 26 & 1,189 & $32.50 \%$ & $45.7 \pm 75.5$ & $1-327$ \\
\hline
\end{tabular}

$\mathrm{n}$ : number of parasitized hosts examined; $\mathrm{N}$ : total number of parasite recovered

\section{DISCUSSION}

The helminths A typica, H. brasiliensis and B. cordiformis have been already reported as parasites of the marine tucuxi in northern Rio de Janeiro State by Santos et al. (1996). This work corroborates their occurrence and reports for the first time the genus Nasitrema in this host. Cetaceans can be definitive hosts of several helminths species and most of them they are infected through the food chain (Dailey and Brownell, 1972). The dolphin's prey species are fish, mollusks and crustaceans, which are the intermediate hosts of their parasites (Geraci and Lounsbury, 1993). In the study area, despite 36 different prey species were eaten by the marine tucuxi, the Atlantic cutlassfish, Trichiurus lepturus, was dominant in its diet, being the preferred prey (Di Beneditto et al., 2001).

Unfortunately, information about the parasitism of the Atlantic cutlassfish along the study area is inexistent. However, Chung et al. (1996) described the high infestation rate of the nematode Anisakis simplex in the intestine of the Atlantic cutlassfish specimens collected in Taiwan. Considering that in the study area A. typica was found in the marine tucuxis examined, this fish could be its intermediate host. Rohde et al. (1995), describing the parasitism of marine fish, found trematodes in the Atlantic cutlassfish, indicating its potential to be intermediate host of these parasites.

Low diversity in parasite species is related to host diet (Aznar et al., 1994). Only four parasite species were recorded in the marine tucuxi along the study area. The narrow range of preferred prey in its diet could be the factor determining the low diversity of parasite groups. The same pattern was recorded for Commerson's dolphin (Cephalorhynchus commersonii) and franciscana (Pontoporia blainvillei) in Argentinian waters (Aznar et al., 1994; Berón-Vera et al., 2001).

The absence of significant differences between sex, maturity and seasons was consistent with recent findings in diet studies. Di Beneditto et al. (2001) did not found differences in diet composition between those features in marine tucuxis collected in northern Rio de Janeiro State. Unfortunately, the lack of quantitative studies about the parasitism of the marine tucuxi along its distribution range did not allow interpopulations' comparisons. More samples are needed to understand the host-parasite interactions in this cetacean species.

\section{ACKNOWLEDGEMENTS}

The authors would like to thank to Dr. Claúdia P. Santos from FIOCRUZ who confirmed the parasite species and Dr. Leandro R. Monteiro from UENF for reviewing this manuscript. We also express our appreciation to the fishermen from Atafona who provided the cetaceans' carcass. A.P.M. Di Beneditto was supported by $\mathrm{CNPq}$ (Process $\mathrm{n}^{\mathrm{o}}$ 300322/03-8). This work is a contribution of the Graduate Program of Ecology and Natural Resources/UENF. 


\section{RESUMO}

Os objetivos deste trabalho foram reportar os helmintos parasitas do tucuxi marinho, Sotalia fluviatilis, na costa norte do Estado do Rio de Janeiro; e checar se a taxa de infestação varia com as características do hospedeiro (sexo e maturidade) e estações do ano. Entre 1989 e 2002, 80 tucuxis marinhos capturados acidentalmente em pescarias foram examinados e quatro espécies de parasitas foram registradas: Braunina cordiformis, Anisakis typica, Halocercus brasiliensis e Nasitrema sp. O parasitismo no tucuxi marinho corrobora seu hábito alimentar e não foram constatadas diferenças nas taxas de infestação entre machos e fêmaes, jovens e adultos, assim como entre as estações do ano. Este trabalho reporta pela primeira vez a ocorrência do gênero Nasitrema no tucuxi marinho.

\section{REFERENCES}

Aznar, F. J.; Balbuena, J. A. and Raga, J. A. (1994), Helminth communities of Pontoporia blainvillei (Cetacea: Pontoporiidae) in Argentinian waters. Can. J. Zool., 72, 702-706.

Berón-Vera, B.; Pedraza, S. N.; Raga, J. A.; Pertierra, A. G.; Crespo, E. A.; Alonso, M. K. and Goodall, N. P. (2001), Gastrointestinal helminthes of Commerson's dolphins Cephalorhynchus commersonii from central Patagonia and Tierra del Fuego. Dis. Aquat. Org., 47, 201-208.

Borobia, M. and Barros, N. B. (1989), Note on the diet of marine Sotalia fluviatilis. Mar. Mamm. Sci., 5, 395-399.

Borobia, M.; Siciliano, S.; Lodi, L. and Hoek, W. (1991), Distribution of the South American dolphin Sotalia fluviatilis. Can. J. Zool., 69, 1025-1039.

Bush, A. O.; Lafferty, K. D.; Lotz, J. M. and Shostak, A. W. (1997), Parasitology meets ecology on its own terms. J. Parasit., 83, 575-583.

Chung, J. G.; Kuo, H. M.; Lin, T. H.; Ho, C. C.; Lee, J. H.; Lai, J. M.; Levy, G. N. and Weber, W. W. (1996), Evidence for arylamine $N$-acetyltransferase in the nematode Anisakis simplex. Cancer Letters, 106, 1-8.

Da Silva, V. M. and Best, R.S. (1996), Sotalia fluviatilis. Mammalian Species, 527, 1-7.

Dailey, M. D. and Brownell Jr., R. L. (1972), A checklist of marine mammals parasites. In: Ridgway, S. (Ed.). Mammals of sea: biology and medicine. New Jersey: Thomas Springfield. pp. 528-589.
Di Beneditto, A. P. M.; Ramos, R. M. and Lima, N. R. (2001), Os golfinhos: origem, classificação, captura acidental, hábito alimentar. Porto Alegre: Cinco Continentes.

Geraci, J. R. and Lounsbury, V. J. (1993), Marine mammals ashore: a field guide for strandings. Texas A\&M Sea Grant Publication, Galveston. 305 pp.

Jefferson, T. A.; Leatherwood, S. and Webber, M. A. (1993), FAO species identification guide: Marine Mammals of the world. Rome: United Nations Environment Programme.

Marigo, J.; Rosas, F. W. and Andrade, A. L. (1999), Intestinal parasites of Sotalia fluviatilis guianensis and Pontoporia blainvillei from the states of Paraná and São Paulo, Brazil. In: Biennial Conference on the Biology of Marine Mammals, 13., Wailea. Proceedings... Wailea, Maui.

Martin, L.; Dominguez, J. L. and Bittencourt, A. C. P. (1998), Climatic control of coastal erosion during a sea-level fall episode. An. Ac. Bras. Ciênc., 70 : (2), 249-266.

Ramos, R. M.; Di Beneditto, A. P. M. and Lima, N. R. (2000), Growth parameteres of Pontopolia blainvillei and Sotalia fluviatils (Cetacea) in northern Rio de Janeiro, Brazil. Aq. Mamm., 26 : (1), 65-75.

Rohde, K.; Hayward, C. and Heap, M. (1995), Aspects of the ecology of metazoan ectoparasites of marine fishes. Int. J. Parasitol., 25 : (8), 945-970.

Santos, C. P.; Rohde, K.; Ramos, R. M.; Di Beneditto, A. P. M. and Capistrano, L. (1996), Helminths of cetaceans on the southeastern coast of Brazil. J. Helminth. Soc. Washington, 63 : (1), 149-152.

Zar, J. H. (1996), Biostatistical analysis. New Jersey: Prentice Hall.
Received: May 10, 2004; Revised: March 17, 2005; Accepted: August 01, 2005. 